\title{
Rapid and complete destruction of perchlorate in water and ion-exchange brine using stabilized zero-valent iron nanoparticles
}

\author{
Zhong Xiong ${ }^{a}$, Dongye Zhao ${ }^{a, *}$, Gang Pan ${ }^{b}$ \\ ${ }^{a} E n v i r o n m e n t a l$ Engineering Program, Department of Civil Engineering, 238 Harbert Engineering Center, Auburn University, \\ Auburn, AL 36849, USA \\ ${ }^{\mathrm{b}}$ Research Center for Eco-Environmental Sciences, Chinese Academy of Sciences, 18 Shuangqing Road, Beijing 100085, China
}

\section{A R T I C L E I N F O}

\section{Article history:}

Received 24 March 2007

Received in revised form

21 May 2007

Accepted 29 May 2007

Available online 3 June 2007

Keywords:

Degradation

Ion-exchange brine

Nanoparticle

Perchlorate

Reduction

Zero-valent iron

Water treatment

\begin{abstract}
A B S T R A C T
Perchlorate has emerged as a widespread contaminant in groundwater and surface water. Because of the unique chemistry of perchlorate, it has been challenging to destroy perchlorate. This study tested the feasibility of using a new class of stabilized zero-valent iron (ZVI) nanoparticles for complete transformation of perchlorate in water or ionexchange brine. Batch kinetic tests showed that at an iron dosage of $1.8 \mathrm{gL}^{-1}$ and at moderately elevated temperatures $\left(90-95^{\circ} \mathrm{C}\right), \sim 90 \%$ of perchlorate in both fresh water and a simulated ion-exchange brine $(\mathrm{NaCl}=6 \%(\mathrm{w} / \mathrm{w}))$ was destroyed within $7 \mathrm{~h}$. An activation energy $\left(E_{\mathrm{a}}\right)$ of $52.59 \pm 8.41 \mathrm{~kJ} \mathrm{~mol}^{-1}$ was determined for the reaction. Kinetic tests suggested that $\mathrm{Cl}(\mathrm{VII})$ in perchlorate was rapidly reduced to chloride without accumulation of any intermediate products. Based on the surface-area-normalized rate constant $k_{\mathrm{SA}}$, starchand CMC-stabilized ZVI nanoparticles degraded perchlorate 1.8 and 3.3 times, respectively, faster than non-stabilized ZVI particles. Addition of a metal catalyst (Al, Cu, Co, Ni, Pd, or Re) did not show any reaction improvement. This technology provides an effective method for complete destruction of perchlorate in both contaminated water and brine.
\end{abstract}

(c) 2007 Elsevier Ltd. All rights reserved.

\section{Introduction}

Perchlorate $\left(\mathrm{ClO}_{4}^{-}\right)$has been primarily used in solid rocket fuels. It is also used in firework powder, roadside flares, airbag inflators, and fertilizers from Chile (Urbansky, 1998). Past massive applications of perchlorate have left a contamination legacy that perchlorate has been detected at about 400 sites in groundwater, surface water, soil, or public drinking water in more than 35 states across the United States, with concentrations ranging from $4 \mu \mathrm{gL}^{-1}$ to more than 3.7 million $\mu \mathrm{gL}^{-1}$ (US Government Accountability Office (USGAO), 2005). Recently, perchlorate was also detected in milk (Kirk et al., 2005) and bottled water (Snyder et al., 2005).
When ingested, perchlorate can impede the endocrine function by blocking iodide from entering the thyroid gland, thereby reducing the production of thyroid hormones. The adverse health effects were reportedly more profound for newborns, children, and pregnant women (Wolff, 1998). A study from the US Centers for Disease Control (CDC) found that almost any amount of perchlorate exposure was linked to a significant change in levels of thyroid hormones (Blount et al., 2006). To reduce human exposure, the USEPA adopted a drinking water equivalent level (DWEL) of $24.5 \mu \mathrm{gL}^{-1}$. Meanwhile, California adopted a public health goal of $6 \mu \mathrm{gL}^{-1}$ and Massachusetts set the nation's first drinking water standard of $2 \mu \mathrm{gL}^{-1}$ for perchlorate.

*Corresponding author. Tel.: +1334 844 6277; fax: +1334844 6290.

E-mail address: dzhao@eng.auburn.edu (D. Zhao).

0043-1354/\$ - see front matter (c) 2007 Elsevier Ltd. All rights reserved.

doi:10.1016/j.watres.2007.05.049 
Perchlorate is highly water soluble, non-complexing, nonvolatile, and chemically stable (Urbansky, 1998). For its unique chemistry, it has been highly challenging to remove perchlorate from water by traditional water treatment approaches (Hatzinger, 2005). In recent years, various treatment technologies have been developed and/or tested, including biological reduction (Logan and LaPoint, 2002; Min et al., 2004; Xu et al., 2003), ion exchange (IX) (Gu et al., 2001, 2003; Tripp and Clifford, 2004, 2006; Xiong et al., 2006), tailored activated carbon sorption (Chen et al., 2005; Parette et al., 2005), filtration (Yoon et al., 2003), and chemical reduction (Moore et al., 2003; Gu et al., 2006). However, these technologies are limited by some critical technical and/or economic drawbacks such as slow degradation kinetics and production of large volumes of concentrated process waste residuals. For instance, IX has been considered as one of the best available technologies for perchlorate removal (Gingras and Batista, 2002), and many commercial IX resins can offer high perchlorate sorption capacity. However, the regeneration efficiency of the IX resins has been found to be prohibitively poor. As a result, current IX processes are used on a disposable basis (i.e. the resin is disposed of after only one service run) or, when resin regeneration is practised, it will result in large volumes of spent regenerant brine. Spent IX brine is typically characterized with high salinity, concentrated perchlorate, and/or mixtures of concentrated acids and salts ( $1 \mathrm{M} \mathrm{FeCl}_{3}$ and $4 \mathrm{M} \mathrm{HCl}$ ) (Gu et al., 2001). Because of the highly stressful conditions, biological treatment of the spent brine is rather challenging. Consequently, cost-effective technologies that can destroy perchlorate in fresh water and regenerant brine are in dire need.

In recent years, zero-valent iron (ZVI) has attracted increasing interest for abiotic dechlorination of chlorinated organic compounds (Wang and Zhang, 1997), removal of nitrate (Huang and Zhang, 2004; Yang and Lee, 2005), reduction of chromate (Wilkin et al., 2005), and sorption of arsenic (Kanel et al., 2006). ZVI was also tested for reduction of perchlorate. For instance, Moore et al. (2003) and Moore and Young (2005) investigated perchlorate removal by commercial iron filings $($ size $=20-100$ mesh, surface area$\left.0.08-5.65 \mathrm{~m}^{2} \mathrm{~g}^{-1}\right)$. Up to $66 \%$ of perchlorate $(0.1 \mathrm{mM})$ was removed in $336 \mathrm{~h}$ at a high iron dosage of $1.25 \mathrm{~g} \mathrm{~mL}^{-1}$. Gurol and Kim (2000) reported that UV light accelerated the perchlorate reduction rate with a dose of $20 \mathrm{gL}^{-1}$ or higher metallic iron (size $=100$ mesh, surface area $=0.74 \mathrm{~m}^{2} \mathrm{~g}^{-1}$ ). Oh et al. (2006a) reported that $98 \%$ of perchlorate in water was reduced by cast iron (surface area $=1.29 \mathrm{~m}^{2} \mathrm{~g}^{-1}$ ) in $1 \mathrm{~h}$ at $200^{\circ} \mathrm{C}$ via microwave heating and at $\mathrm{pH}$ 7.4. In another study, Oh et al. (2006b) reported that perchlorate in wastewater was completely removed by iron at an elevated temperature of $150^{\circ} \mathrm{C}$ in $6 \mathrm{~h}$ without $\mathrm{pH}$ control. Cao et al. (2005) observed that non-stabilized iron particles were able to degrade perchlorate at temperatures from 25 to $75^{\circ} \mathrm{C}$.

Because ZVI-based reactions are surface-mediated processes, increasing surface area of ZVI was found to increase the reaction rates (Wang and Zhang, 1997). It has been reported that decreasing the size of ZVI particles to the nanoscale can greatly enhance the reaction rates for perchlorate reduction (Cao et al., 2005) and nitrate removal (Yang and Lee, 2005). However, because nanoscale ZVI particles tend to agglomerate rapidly (in a few minutes) (He and Zhao, 2005; He et al., 2007), the "nanoparticles" without a stabilizer are actually agglomerates or flocs of ZVI particles in the micron scale.

To maximize the reactivity of ZVI nanoparticles, $\mathrm{He}$ and Zhao (2005) and He et al. (2007) modified the conventional water-based approach for preparing ZVI nanoparticles by applying a food-grade water-soluble starch or sodium carboxymethyl cellulose (CMC) as a stabilizer. Compared with conventional non-stabilized ZVI "nanoparticles", the stabilized nanoparticles displayed much greater surface area, superior physical stability, and much faster TCE-dechlorination rates.

This present study aims to test the feasibility of using starch- or CMC-stabilized ZVI nanoparticles for perchlorate destruction in fresh water or in spent IX regenerant brine or contaminated saline water. The specific objectives are to (1) determine the rate and extent of perchlorate reduction by stabilized ZVI nanoparticles and (2) characterize the influences of temperature, salinity, and $\mathrm{pH}$ on the reactivity of the nanoparticles.

\section{Materials and methods}

\subsection{Chemicals}

The following chemicals were used as received: 4-(2-hydroxyethyl)-1-piperazineethane ethanesulfonic acid (HEPES, $\mathrm{C}_{8} \mathrm{H}_{18} \mathrm{~N}_{2} \mathrm{O}_{4} \mathrm{~S}$ ) (Fisher, Fair Lawn, NJ, USA); aluminum chloride $\left(\mathrm{AlCl}_{3} \cdot 6 \mathrm{H}_{2} \mathrm{O}\right)$ (Fisher); cobalt chloride $\left(\mathrm{CoCl}_{2} \cdot 6 \mathrm{H}_{2} \mathrm{O}\right)$ (Fisher); cupric chloride $\left(\mathrm{CuCl}_{2} \cdot 2 \mathrm{H}_{2} \mathrm{O}\right)$ (Fisher); ferrous sulfate (FeS$\mathrm{O}_{4} \cdot 7 \mathrm{H}_{2} \mathrm{O}$ ) (Acros Organics, Morris Plains, NJ, USA); methyltrioxorhenium (VII) $\left(\mathrm{MeReO}_{3}, 98 \%\right)$ (Strem Chemicals, Newburyport, MA, USA); nickel chloride $\left(\mathrm{NiCl}_{2} \cdot 6 \mathrm{H}_{2} \mathrm{O}\right)$ (Fisher); potassium hexachloropalladate $\left(\mathrm{K}_{2} \mathrm{PdCl}_{6}, 99 \%\right)$ (Acros Organics); sodium borohydride $\left(\mathrm{NaBH}_{4}\right)$ (MP Biomedicals, Aurora, $\mathrm{OH}, \mathrm{USA}$ ); sodium carboxymethyl cellulose ( $\mathrm{MW}=90,000$, $\mathrm{DS}=0.7$ ) (Acros Organics); sodium chloride ( $\mathrm{NaCl}$ ) (Fisher); sodium chlorate $\left(\mathrm{NaClO}_{3}\right.$, laboratory grade) (Fisher); sodium chlorite $\left(\mathrm{NaClO}_{2}, 80 \%\right)$ (Fisher); sodium hypochlorite (NaClO) (Acros Organics); sodium perchlorate $\left(\mathrm{NaClO}_{4},>98 \%\right)$ (Aldrich, St. Louis, MO, USA); and a water-soluble starch (Alfa Aesar, Ward Hill, MA, USA).

\subsection{Preparation of stabilized ZVI nanoparticles}

Stabilized ZVI nanoparticles were prepared following a procedure reported previously (He and Zhao, 2005; He et al., 2007). In brief, the preparation was carried out in a $500 \mathrm{~mL}$ flask attached to a vacuum line. A solution containing $1.2 \%$ $(\mathrm{w} / \mathrm{w})$ starch or $1.2 \%$ CMC was prepared by dissolving a watersoluble starch or CMC with deionized (DI) water and then the solutions were purged with purified $\mathrm{N}_{2}$ for half an hour to remove dissolved oxygen (DO). A stock solution of $0.2 \mathrm{M}$ $\mathrm{FeSO}_{4} \cdot 7 \mathrm{H}_{2} \mathrm{O}$ was also prepared with DI water. The FeS$\mathrm{O}_{4} \cdot 7 \mathrm{H}_{2} \mathrm{O}$ stock solution was then added to the starch or CMC solution through a buret to yield a final concentration of $2 \mathrm{gL}^{-1}$ of iron and $1 \%(\mathrm{w} / \mathrm{w})$ of starch or CMC. The mixture was purged with $\mathrm{N}_{2}$ for half an hour to remove DO and to mix 
the solution. Fe(II) ions were then reduced to $\mathrm{Fe}(0)$ nanoparticles by adding a stoichiometric amount of sodium borohydride to the mixture. To ensure efficient use of the reducing agent, the reactor system was operated under inert conditions through continuous vacuuming. The flask was handshaken intermittently during the preparation. When gas (hydrogen) evolution ceased (after $15 \mathrm{~min}$ ), the ZVI nanoparticles were ready for use. To test the effect of metal catalysts, a second metal ( $\mathrm{Al}, \mathrm{Cu}, \mathrm{Co}, \mathrm{Ni}$, or $\mathrm{Pd}$ ) solution was added at $0.3 \%(\mathrm{w} / \mathrm{w})$ of Fe to the ZVI nanoparticles to yield a class of stabilized bimetallic nanoparticles. To test the catalytic effect of rhenium (Re), various masses of solid methyltrioxorhenium $\left(\mathrm{MeReO}_{3}\right)$ were dissolved to select Fe-Pd suspensions to achieve desired catalyst concentrations. For comparison, non-stabilized ZVI nanoparticles were also prepared following the same procedure but without the addition of a stabilizer.

\subsection{TEM and DLS characterization}

Transmission electron micrograph (TEM) images were obtained using a Zeiss EM10 transmission electron microscope (Zeiss, Thornwood, NJ) operated at 25 and $40 \mathrm{kV}$. The TEM image was analyzed using a specialty image-processing software ImageJ to obtain the particle size. Detailed procedures on the sample preparation and analyses were reported elsewhere (He and Zhao, 2005).

Dynamic light scattering (DLS) tests were performed with a Nicomp 380 Submicron Particle Sizer (PSS, Santa Barbara, CA) at a measurement angle of $90^{\circ}$ (Internal $\mathrm{He}-\mathrm{Ne}$ laser, wavelength $633 \mathrm{~nm}$ ). DLS measures the dynamic particle size distribution of the nanoparticles in situ (aqueous solution). The particle size was measured based on number weighting, and the minimum particle diameter was set at $1 \mathrm{~nm}$. The viscosity of various nanoparticle suspensions was measured with a Gilmont falling ball viscometer and then used to correct the influence of viscosity on particle mobility. Before the measurements, freshly prepared nanoparticle suspensions were first diluted to $0.1 \mathrm{gL}^{-1}$ with nitrogen-purged $0.2 \%$ CMC or starch solutions. Samples were placed in the machine for 5 min prior to start of the measurements. Each sample was measured three times (10 min each). The DLS data were then processed with a software package (CW380) to yield the number-weighted size distributions.

\subsection{Degradation of perchlorate}

Batch kinetic tests for perchlorate degradation by the nanoparticles were carried out using $25 \mathrm{~mL}$ glass vials. The degradation was initiated by mixing $2.5 \mathrm{~mL}$ of a perchlorate stock solution (1.0-10.0 mM) and $22.5 \mathrm{~mL}$ of a certain type of ZVI nanoparticle suspension $\left(2 \mathrm{gL}^{-1} \mathrm{Fe}\right)$, which resulted in an initial $\mathrm{ClO}_{4}^{-}$concentration of either 10 or $100 \mathrm{mgL}^{-1}$. These initial concentration values are within the range of reported perchlorate levels, especially in the source zones (USGAO, 2005) or in spent IX brine, and are comparable to those studied by other researchers (Cao et al., 2005; Hurley and Shapley, 2007; Moore et al., 2003; Oh et al., 2006a,b). In all cases, a ZVI dose of $1.8 \mathrm{gL}^{-1}$ was tested, which required a stabilizer (CMC or starch) concentration of $0.9 \%(\mathrm{w} / \mathrm{w})$ to maintain effective particle stabilization. The iron dose amounts to the lower end of the range (1.0-20.0 $\mathrm{gL}^{-1}$ of nonstabilized ZVI) tested by Cao et al. (2005). Higher concentrations of ZVI were also prepared, but it would require the stabilizer concentration to be increased accordingly. Our tests indicated that when CMC exceeded $1.2 \%$ (w/w), it became gelatinized upon heating, and thus no longer suitable for the desired uses. The vials were then sealed with Teflon-lined caps, and placed in an oven (Thelco model 28, Gca/Precision Scientific), which was set at a desired temperature. We observed that stirring at $40 \mathrm{rpm}$ on a rotator (Glas-Col, Terre Haute, IN, USA) at $80^{\circ} \mathrm{C}$ showed no significant effect on perchlorate reduction kinetics. Therefore, no stirring was provided in all tests. At predetermined times, duplicate sample vials were sacrificed for analyzing remaining perchlorate. Typically, $\sim 0.5 \mathrm{~mL}$ of sample was diluted with acidified DI water $(\mathrm{pH}=3)$ by $10-100$ times to convert the remaining ZVI nanoparticles to soluble $\mathrm{Fe}(\mathrm{II})$, and then analyzed for perchlorate and reduction by-products such as chlorate, chlorite, hypochlorite, and chloride. Control experiments were carried out without the nanoparticles but under otherwise identical conditions.

To test $\mathrm{pH}$ effect, the degradation experiments were carried out at an initial $\mathrm{pH}$ ranging from 5.1 to 8.5 adjusted with $0.1 \mathrm{~N}$ $\mathrm{NaOH}$ and/or $0.1 \mathrm{~N} \mathrm{HCl}$, or at $\mathrm{pH} 7.0-7.4$ by adding 5 mM HEPES buffer solution to the vials.

\subsection{Chemical analyses}

Anions $\left(\mathrm{ClO}_{4}^{-}, \mathrm{ClO}_{3}^{-}, \mathrm{ClO}_{2}^{-}, \mathrm{ClO}^{-}, \mathrm{Cl}^{-}\right)$were analyzed using a Dionex ion chromatograph (DX-120) equipped with a suppressed conductivity detector. $\mathrm{ClO}_{4}^{-}$was analyzed using an AS16 column, an AG16 guard column, and a $1000 \mu \mathrm{L}$ sample loop. A degassed $50 \mathrm{mM}$ sodium hydroxide solution was used as the eluent. The detection limit for perchlorate was $4 \mu \mathrm{gL}^{-1}$. $\mathrm{ClO}_{3}^{-}, \mathrm{ClO}_{2}^{-}, \mathrm{ClO}^{-}$, and $\mathrm{Cl}^{-}$were analyzed using an $\mathrm{AS} 14$ column, an AG14 guard column, and a $100 \mu \mathrm{L}$ sample loop. Detection limits for $\mathrm{ClO}_{3}^{-}, \mathrm{ClO}_{2}^{-}, \mathrm{ClO}^{-}$, and $\mathrm{Cl}^{-}$were $0.1,0.1$, 0.05 , and $0.05 \mathrm{mgL}^{-1}$, respectively. A solution containing $3.5 \mathrm{mM}$ sodium carbonate and $1.0 \mathrm{mM}$ sodium bicarbonate was used as the eluent. The eluent flow rate was set at $1.0 \mathrm{~mL} \mathrm{~min}^{-1}$.

\section{Results and discussion}

\subsection{Characterization of nanoparticles}

Fig. 1 shows the TEM image of ZVI nanoparticles prepared at $2 \mathrm{gL}^{-1} \mathrm{Fe}$ and stabilized with 1\% CMC. The stabilized ZVI nanoparticles appeared as discrete nanoparticles and remained dispersed in water for more than 1 week. Five TEM images including 1711 particles were analyzed for estimating the particle size. The mean size of the freshly prepared CMCstabilized nanoparticles was estimated to be $11.2 \pm 7.9 \mathrm{~nm}$ (standard deviation). Meanwhile, DLS tests were also carried out to obtain the dynamic "wet" particle size distribution. The DLS results gave a particle diameter of $13.7 \pm 2.3 \mathrm{~nm}(99.9 \%$ particles by number), which appears to agree with TEM-based "dry" particle size. Based on a mean diameter of $13.7 \mathrm{~nm}$, the 


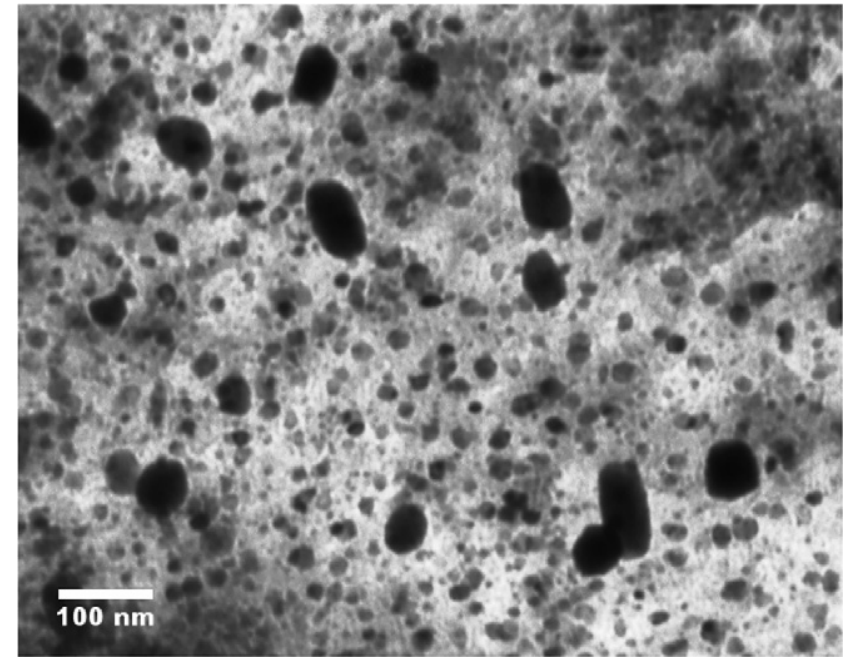

Fig. 1 - TEM image of fresh ZVI nanoparticles stabilized with $1 \%(w / w)$ CMC. The scale bar represents $100 \mathrm{~nm}$.

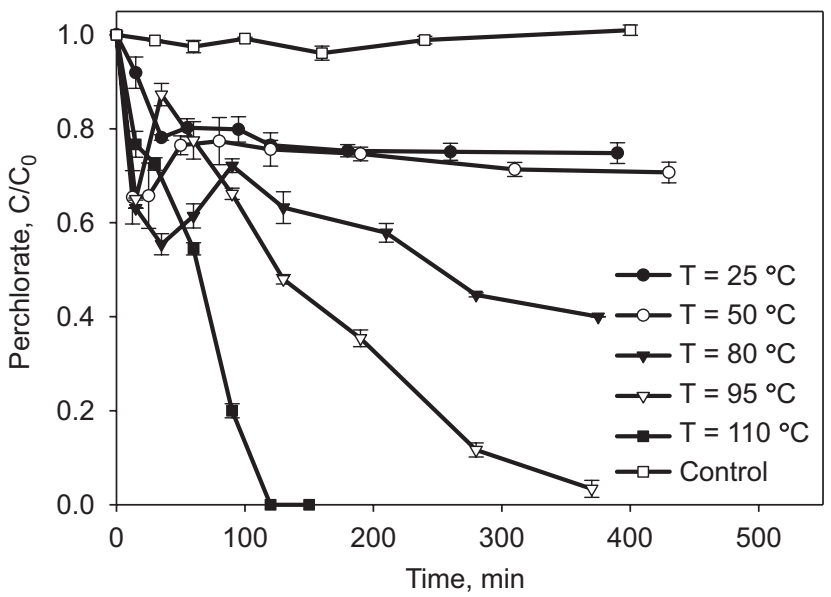

Fig. 2 - Perchlorate reduction by CMC-stabilized ZVI nanoparticles at various temperatures. Initial $\left[\mathrm{ClO}_{4}^{-}\right]=10 \mathrm{mg} \mathrm{L}^{-1}, \mathrm{ZVI}=1.8 \mathrm{~g} \mathrm{~L}^{-1}, \mathrm{CMC}=0.9 \%(\mathrm{w} / \mathrm{w})$, initial $\mathrm{pH}\left(\mathrm{pH}_{0}\right)=6.5$, and final $\mathrm{pH}\left(\mathrm{pH}_{\mathrm{f}}\right)=7.5-7.8$. Control tests were performed at $110^{\circ} \mathrm{C}$ with no ZVI. Data plotted as mean of duplicates, and errors refer to standard deviation.

surface area was calculated to be $55.6 \mathrm{~m}^{2} \mathrm{~g}^{-1}$ following the method by He and Zhao (2005). DLS tests were also carried out for the starch-stabilized ZVI nanoparticles. A mean particle diameter of $22.6 \pm 2.8 \mathrm{~nm}(99.9 \%$ by number) was obtained, which translates into a surface area of $33.7 \mathrm{~m}^{2} \mathrm{~g}^{-1}$.

\subsection{Kinetics and activation energy of perchlorate reduction}

Fig. 2 shows the perchlorate reduction kinetics using $1.8 \mathrm{gL}^{-1}$ ZVI nanoparticles stabilized with $0.9 \% \mathrm{CMC}(\mathrm{w} / \mathrm{w})$ at temperatures ranging from 25 to $110^{\circ} \mathrm{C}$. The initial $\mathrm{pH}$ was $\sim 6.5$ and the final $\mathrm{pH}$ was $7.5-7.8$ after $6 \mathrm{~h}$. At $25^{\circ} \mathrm{C}$, the degradation proceeded slowly with only $23 \%$ of perchlorate reduced in $6 \mathrm{~h}$. When the temperature was raised to $50,80,95$, and $110^{\circ} \mathrm{C}$, the reaction was accelerated progressively. At $95^{\circ} \mathrm{C}$, 97\% perchlo- rate was eliminated in $6 \mathrm{~h}$, and at $110^{\circ} \mathrm{C}$, complete perchlorate degradation was achieved within only $2 \mathrm{~h}$. It is noteworthy that the perchlorate reduction (except at $110^{\circ} \mathrm{C}$ ) displayed a rapid initial drop, and then bounced back up briefly before perchlorate was further degraded. A similar kinetic profile was also observed by Moore et al. (2003) and Moore and Young (2005), who tested the effectiveness of commercial iron filings for perchlorate degradation. In the perchlorate-laden solution, ZVI nanoparticles undergo the following competitive reactions (Gu et al., 2003; Cao et al., 2005):

$\mathrm{Fe}^{0}+2 \mathrm{H}_{2} \mathrm{O}=\mathrm{Fe}^{2+}+\mathrm{H}_{2}+2 \mathrm{OH}^{-}$,

$\mathrm{ClO}_{4}^{-}+4 \mathrm{Fe}^{0}+8 \mathrm{H}^{+}=4 \mathrm{Fe}^{2+}+\mathrm{Cl}^{-}+4 \mathrm{H}_{2} \mathrm{O}$

As the reactions proceed, the surface of the ZVI nanoparticles is progressively oxidized to iron oxides. In the experimental $\mathrm{pH}$ range (6.5-7.8), the resultant iron oxides can rapidly adsorb $\mathrm{ClO}_{4}^{-}$from water, resulting in the observed rapid drop in perchlorate concentration in the solution phase. However, the concurrent rapid adsorption and reduction of perchlorate rapidly depletes the perchlorate chemical potential in the solution phase such that the concentration gradient between the particle surface and the solution phase was reversed, and the sorbed perchlorate started releasing back into the solution. The perchlorate desorption was even further promoted as the concentration of chloride ions resulting from the reduction of perchlorate built up. At elevated temperatures (e.g. $110^{\circ} \mathrm{C}$ ), the perchlorate sorption became thermodynamically less favored, whereas the perchlorate reduction was overwhelmingly enhanced. As a result, the "dipping" effect was less significant at higher temperatures. As will be discussed later in the chlorine mass balance study, the sorption/desorption process was a rather short-lived process and became negligible after $100 \mathrm{~min}$ of the reaction.

The degradation kinetic data can be interpreted using a pseudo-first-order rate model, Eq. (3), following the approach by Johnson et al. (1996):

$\frac{\mathrm{d}\left[\mathrm{ClO}_{4}^{-}\right]}{\mathrm{dt}}=-k_{\mathrm{SA}} a_{\mathrm{s}} \rho_{\mathrm{m}}\left[\mathrm{ClO}_{4}^{-}\right]=-k_{\mathrm{obs}}\left[\mathrm{ClO}_{4}^{-}\right]$,

where $\left[\mathrm{ClO}_{4}^{-}\right]$is the perchlorate concentration $\left(\mathrm{mgL}^{-1}\right)$ in water at time $t(\mathrm{~min}), k_{\mathrm{SA}}$ is the specific reaction rate constant based on surface area of the nanoparticles $\left(\mathrm{L} \mathrm{min}^{-1} \mathrm{~m}^{-2}\right), a_{\mathrm{s}}$ is the specific surface area of the nanoparticles $\left(\mathrm{m}^{2} \mathrm{~g}^{-1}\right), \rho_{\mathrm{m}}$ is the mass concentration of the nanoparticles $\left(\mathrm{gL}^{-1}\right)$, and $k_{\mathrm{obs}}$ is the observed pseudo-first-order rate constant $\left(\mathrm{min}^{-1}\right)$. Because the model describes only reactive degradation of perchlorate, it is only used for the degradation data after perchlorate concentration was recovered from the sorption/ desorption perturbation step. A similar data-fitting approach was also used by Moore et al. (2003) to determine perchlorate reduction rates by $\mathrm{ZVI}$ filings.

Fig. 3 shows linearized plots $\left(\ln \left(C / C^{\prime}{ }_{0}\right)\right.$ vs. time) of the experimental and model-simulated kinetic data, where $C_{0}^{\prime}$ denotes the perchlorate concentration right after the perchlorate concentration profile was recovered from the initial sorption/desorption dip and where the perchlorate concentration began to drop again. Table 1 gives the fitted model parameters. Fairly good model fitting $\left(R^{2}>0.90\right)$ was obtained. 


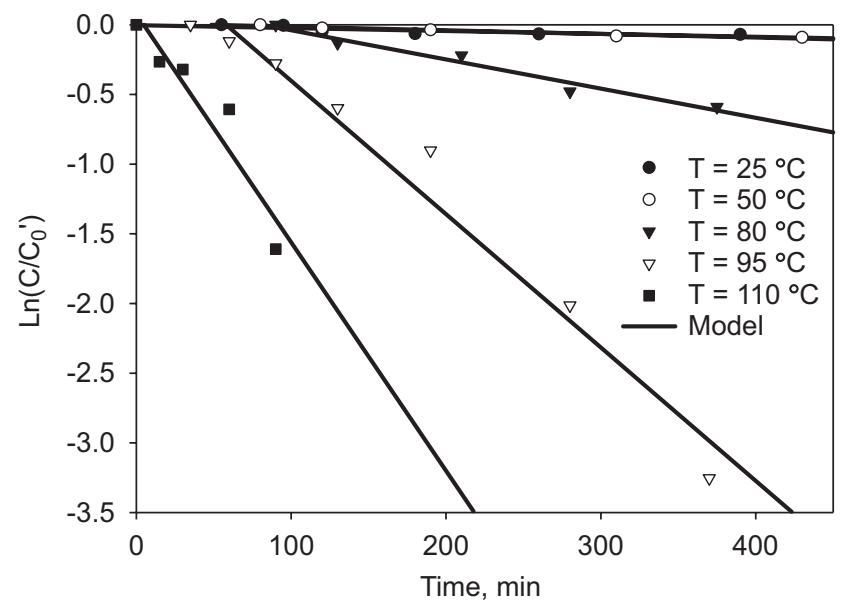

Fig. 3 - Fitting a pseudo-first-order model to the experimental perchlorate reduction rate data of Fig. 2. Symbols: experimental data; lines: model fittings.

Table 1 - Observed pseudo-first-order rate constant of perchlorate reduction by CMC-stabilized iron nanoparticles at various temperatures

\begin{tabular}{lcc}
\hline Temperature $\left({ }^{\circ} \mathrm{C}\right)$ & $k_{\text {obs }}\left(\mathrm{min}^{-1}\right)$ & $R^{2}$ \\
\hline 25 & 0.0002 & 0.96 \\
50 & 0.0003 & 0.94 \\
80 & 0.0021 & 0.97 \\
95 & 0.0096 & 0.97 \\
110 & 0.0164 & 0.90
\end{tabular}

Evidently, the observed pseudo-first-order rate constant ( $\left.k_{\text {obs }}\right)$ was improved by 82 times when the temperature was increased from 25 to $110^{\circ} \mathrm{C}$.

The degradation enhancement at elevated temperatures can be easily revealed when the experimental data are plotted in accord with the linearized Arrhenius equation

$\ln k_{\mathrm{obs}}=\ln \mathrm{A}-\frac{E_{\mathrm{a}}}{R T}$,

where $A$ is a constant, $E_{\mathrm{a}}$ the activation energy $\left(\mathrm{kJ} \mathrm{mol}^{-1}\right), \mathrm{R}$ the universal gas constant $\left(8.314 \mathrm{JK}^{-1} \mathrm{~mol}^{-1}\right)$, and $\mathrm{T}$ the absolute temperature $(\mathrm{K})$.

Fig. 4 also gives an activation energy $\left(E_{a}\right)$ of $52.59 \pm 8.41 \mathrm{~kJ} \mathrm{~mol}^{-1}$ and an A value of 194,075 for the CMCstabilized ZVI nanoparticles. This relatively high level of activation energy is associated with the unique chemistry of perchlorate. Although the chlorine in perchlorate is at its highest oxidation state (+7), and thus reduction of perchlorate is thermodynamically favorable, perchlorate is quite inert toward most of the common reducing agents due to the high kinetic barrier (Urbansky, 1998). However, the activation energy $\left(E_{\mathrm{a}}\right)$ determined in this study is much lower than those reported by others. For example, Gu et al. (2003) reported an activation energy of $120 \pm 5 \mathrm{~kJ} \mathrm{~mol}^{-1}$ when ferrous iron was used to reduce a perchlorate waste residual containing ferric chloride and hydrochloric acid at elevated temperatures (up to $200^{\circ} \mathrm{C}$ ) and/or pressure ( $\left.20 \mathrm{~atm}\right)$. Cao et al. (2005) reported an activation energy of $79.02 \pm 7.75 \mathrm{~kJ} \mathrm{~mol}^{-1}$ for

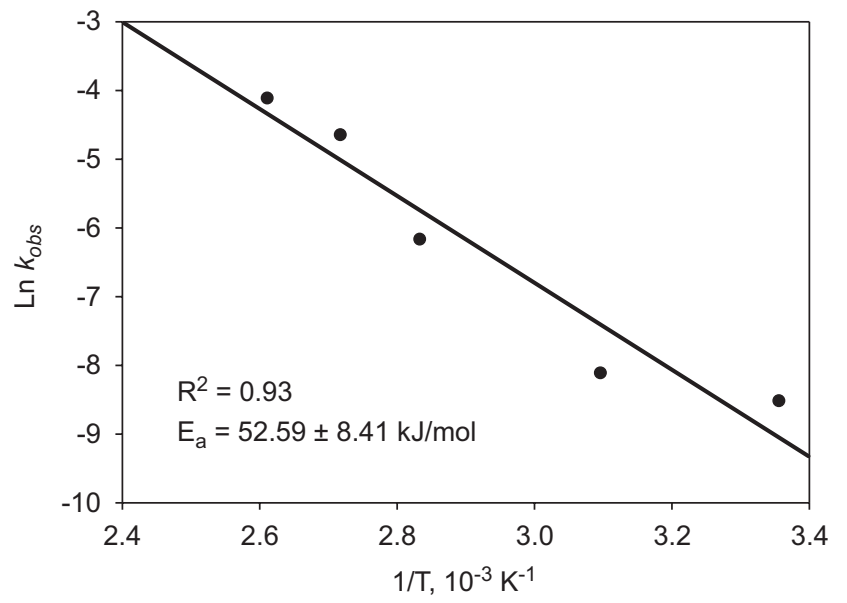

Fig. 4 - Linearized Arrhenius plot of the observed first-order rate constant (Table 1 ) as a function of $1 / T$.

reduction of perchlorate $\left(200 \mathrm{mgL}^{-1}\right)$ by non-stabilized ZVI particles at various ZVI doses $\left(1.0-20.0 \mathrm{gL}^{-1}\right)$. The ZVI nanoparticles serve as both a reactant (electron donor) and a catalyst (Lowry and Liu, 2006). Accordingly, the much lower activation energy for the CMC-stabilized ZVI can be attributed to two factors. First, the presence of CMC greatly enhances the surface reactivity of the ZVI nanoparticles. As will be illustrated later on, the surface-normalized rate constant $\left(K_{\mathrm{SA}}\right)$ for CMC-stabilized ZVI is 3.3 times greater than that for non-stabilized ZVI. Second, the presence of CMC may also boost the catalytic activity of the ZVI nanoparticles. Both enhanced surface reactivity and elevated catalytic activity can result in a reaction pathway of much lower activation energy for perchlorate degradation.

\subsection{Chlorine mass balance and reaction completeness}

Perchlorate reduction follows the sequential reactions below (Rikken et al., 1996; Gu et al., 2003; Cao et al., 2005):

$\mathrm{ClO}_{4}^{-} \rightarrow \mathrm{ClO}_{3}^{-} \rightarrow \mathrm{ClO}_{2}^{-} \rightarrow \mathrm{ClO}^{-} \rightarrow \mathrm{Cl}^{-}$.

Thus, the completeness of perchlorate reduction can be revealed by following the production of chlorate, chlorite, hypochlorite, and/or chloride in the system. The concentration of chlorine-containing species $\left(\mathrm{ClO}_{4}^{-}, \mathrm{ClO}_{3}^{-}, \mathrm{ClO}_{2}^{-}, \mathrm{ClO}^{-}\right.$, and $\mathrm{Cl}^{-}$) was measured during a set of batch kinetic experiments. Fig. 5 shows the concentrations of $\mathrm{ClO}_{4}^{-}$and $\mathrm{Cl}^{-}$as well as the total chlorine-containing species against reaction time. Because $\mathrm{ClO}_{3}^{-}, \mathrm{ClO}_{2}^{-}$, and $\mathrm{ClO}^{-}$were not detected during the tests, the total chlorine-containing species was actually the sum of $\mathrm{ClO}_{4}^{-}$and $\mathrm{Cl}^{-}$.

While chloride production increased steadily with time, perchlorate displayed an initial concentration dip due to the initial sorption/desorption effect. Because of the initial rapid adsorption, the measured total chlorine species at $\sim 20 \mathrm{~min}$ accounted for only $72 \%$ of the total $\mathrm{ClO}_{4}^{-}$initially added in the system, which suggests that a significant fraction of perchlorate added was initially adsorbed to the nanoparticles without being degraded. After $\sim 60 \mathrm{~min}$, when the effect of sorption/desorption became less significant, the sum of $\mathrm{ClO}_{4}^{-}$ 


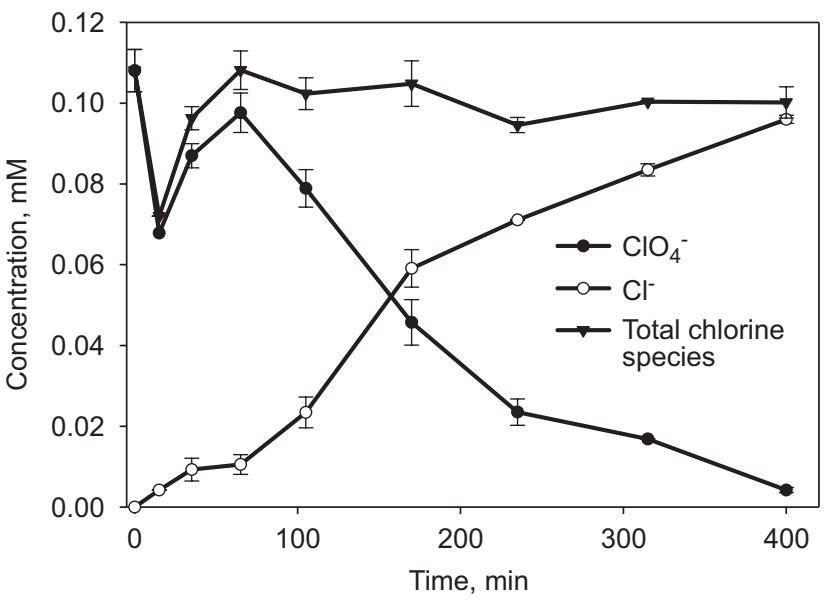

Fig. 5 - Chlorine mass balance during perchlorate reduction by CMC-stabilized ZVI nanoparticles. Initial $\left[\mathrm{ClO}_{4}^{-}\right]=10 \mathrm{mg} \mathrm{L}^{-1}, \mathrm{zVI}$ dose $=1.8 \mathrm{~g} \mathrm{~L}^{-1}, \mathrm{CMC}=0.9 \%(\mathrm{w} / \mathrm{w})$, $\mathrm{pH}_{0}=6.6-6.8$ and $\mathrm{pH}_{\mathrm{f}}=7.7-7.8$. Data plotted as mean of duplicates, and errors refer to standard deviation.

and $\mathrm{Cl}^{-}$accounted for $93-101 \%$ of total $\mathrm{ClO}_{4}^{-}$initially added in the system. The nearly perfect mass balance indicates that (1) the initially strong sorption and desorption of perchlorate became negligible after $\sim 60 \mathrm{~min}$ and (2) perchlorate was nearly completely reduced to chloride without production of significant amounts of intermediate products such as $\mathrm{ClO}_{3}^{-}$, $\mathrm{ClO}_{2}^{-}$, and $\mathrm{ClO}^{-}$.

\subsection{Perchlorate reduction by various iron nanoparticles}

He and Zhao (2005) and He et al. (2007) reported that both water-soluble starch and CMC can stabilize ZVI nanoparticles. In addition, they reported that addition of a metal catalyst such as Pd on the ZVI nanoparticles can greatly catalyze degradation of chlorinated hydrocarbons. To test the effect of stabilizer type and metal catalysts on the perchlorate degradation, parallel kinetic tests were carried out using non-stabilized ZVI particles, starch- or CMC-stabilized ZVI nanoparticles, and stabilized nanoparticles with a metal catalyst (i.e. $\mathrm{Al}, \mathrm{Cu}, \mathrm{Co}, \mathrm{Ni}, \mathrm{Pd}$, or $\mathrm{Re}$ ).

Fig. 6 compares perchlorate degradation rates for various particles at $110^{\circ} \mathrm{C}$ under otherwise identical conditions. Again, Eq. (3) was used to interpret the experimental data, and Table 2 gives the fitted model parameters. Based on the $k_{\text {obs }}$ values, starch- and CMC-stabilized ZVI nanoparticles degraded perchlorate 1.8 and 5.5 times, respectively, faster than non-stabilized ZVI particles. Based on the surface-areanormalized rate constant $k_{\mathrm{SA}}$, starch- and CMC-stabilized ZVI nanoparticles degraded perchlorate 1.8 and 3.3 times, respectively, faster than non-stabilized ZVI particles. These improved $k_{\mathrm{SA}}$ values suggest that stabilizers not only increased the surface area of the nanoparticles (because of the much smaller particle size), but also resulted in a more reactive particle surface. On the other hand, the $k_{\mathrm{SA}}$ value for CMCstabilized ZVI nanoparticles is more than two orders of magnitude greater than that for a cast iron (surface area$1.29 \mathrm{~m}^{2} \mathrm{~g}^{-1}$ ) reported by Oh et al. (2006a).

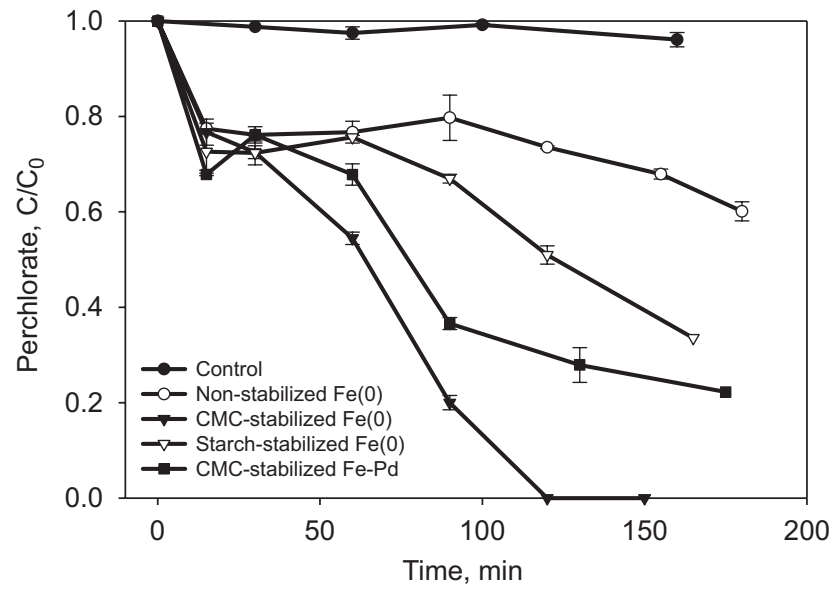

Fig. 6 - Perchlorate reduction by various ZVI-based particles. For all cases, $\mathrm{ZVI}$ dose $=1.8 \mathrm{~g} \mathrm{~L}^{-1}$, initial $\left[\mathrm{ClO}_{4}^{-}\right]=10 \mathrm{mg} \mathrm{L}^{-1}$, $\mathrm{pH}_{0}=6.5-6.8, \mathrm{pH}_{\mathrm{f}}=7.5-7.8$, and temperature $=110^{\circ} \mathrm{C}$; for stabilized ZVI nanoparticles, starch or CMC $=0.9 \%(w / w)$; for Fe-Pd bimetallic nanoparticles, $\mathrm{Pd}=0.3 \%$ of $\mathrm{Fe}(\mathrm{w} / \mathrm{w})$. Data plotted as mean of duplicates, and errors refer to standard deviation.

The $k_{\text {obs }}$ and $k_{\mathrm{SA}}$ for CMC-stabilized nanoparticles are 3.0 and 1.8 times, respectively, greater than for starch-stabilized nanoparticles. This observation indicates that CMC is a more efficient stabilizer than starch, i.e. CMC gives not only smaller but also more reactive ZVI nanoparticles. The more effective particle stabilization of CMC is attributed to its carboxymethyl groups that interact with Fe(II) as well as the nanoparticles more strongly than the hydroxyl groups of starch do (He et al., 2007).

Interestingly, the presence of a second metal (e.g. Pd added at $0.3 \%$ of $\mathrm{Fe}$ ) reduced $k_{\text {obs }}$ and $k_{\mathrm{SA}}$ by $44.5 \%$. Similar inhibitive effects were also observed when other metals such as $\mathrm{Al}, \mathrm{Co}$, $\mathrm{Cu}$, and $\mathrm{Ni}$ were used (data not shown). When a second metal is added to the ZVI suspensions, the following redox reaction will take place:

$n \mathrm{Fe}^{0}+2 \mathrm{Me}^{n+}=n \mathrm{Fe}^{2+}+2 \mathrm{Me}^{0}$.

However, this reaction should not consume the reducing power of the ZVI nanoparticles to any appreciable extent, given the minimal amount of the second metal added. The significant drop in perchlorate reduction rate with the catalysts is then primarily attributed to the fact that the metal catalysts can catalyze the corrosion reaction of the ZVI nanoparticles (Eq. (1)). This accelerated side reaction rendered more profound loss in the reducing power of the $\mathrm{ZVI}$ nanoparticles toward perchlorate. Cao et al. (2005) reported that addition of Pd or Ag to non-stabilized ZVI particles showed no performance enhancement for perchlorate degradation.

Rhenium has been well recognized to be able to catalyze perchlorate reduction through an oxygen transfer reaction (Cai and Espenson, 2005; Abu-Omar et al., 2000; Abu-Omar, 2006). A recent study reported that perchlorate was reduced completely to chloride within $24 \mathrm{~h}$ by hydrogen ( $40 \mathrm{psig}$ ) in the presence of methyltrioxorhenium $\left(\mathrm{MeReO}_{3}, 0.5 \mathrm{mM}\right)$ and 
Table 2 - Physical parameters and perchlorate reduction rate constants for various iron nanoparticles at $110{ }^{\circ} \mathrm{C}$

\begin{tabular}{lcccc}
\hline Type of nanoparticles & $a_{\mathrm{s}}\left(\mathrm{m}^{2} \mathrm{~g}^{-1}\right)$ & $\rho_{\mathrm{m}}\left(\mathrm{gL}^{-1}\right)$ & $k_{\mathrm{obs}}\left(\mathrm{min}^{-1}\right)$ & $k_{\mathrm{SA}}\left(10^{-5} \mathrm{~L} \mathrm{~min}^{-1} \mathrm{~m}^{-2}\right)$ \\
\hline Non-stabilized Fe & $33.5^{\mathrm{a}}$ & 1.8 & 0.0030 & 5.0 \\
Starch-stabilized Fe & 33.7 & 1.8 & 0.0055 & 9.1 \\
CMC-stabilized Fe & 55.6 & 1.8 & 0.0164 & 16.4 \\
CMC-stabilized Fe/Pd & 55.6 & 1.8 & 0.0091 & 9.1 \\
\hline${ }^{2}$ From Wang and Zhang (1997). & & & \\
\hline
\end{tabular}

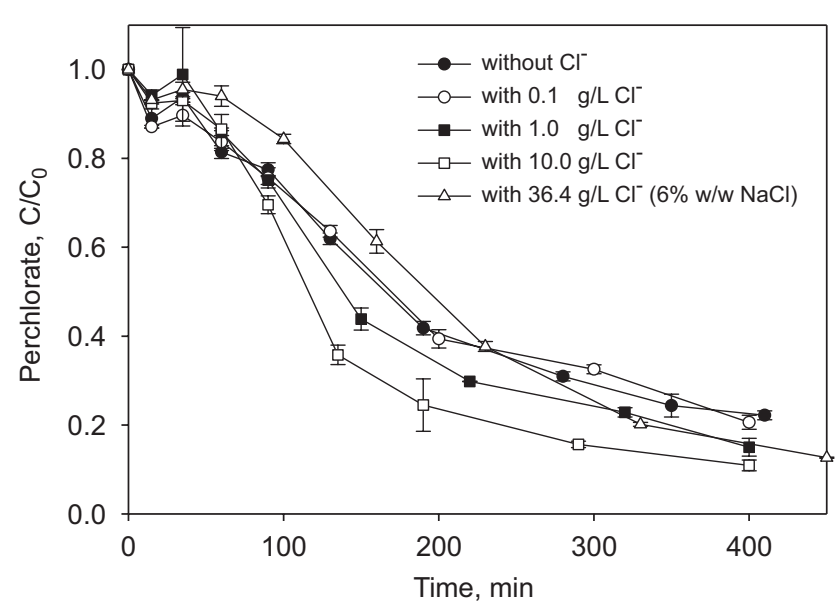

Fig. 7 - Perchlorate reduction by CMC-stabilized ZVI nanoparticles in the presence of various background chloride concentrations at $95^{\circ} \mathrm{C}$. Initial $\left[\mathrm{ClO}_{4}^{-}\right]=100 \mathrm{mg} \mathrm{L}^{-1}$, $\mathrm{ZVI}$ dose $=1.8 \mathrm{~g} \mathrm{~L}^{-1}, \mathrm{CMC}=0.9 \%(\mathrm{w} / \mathrm{w}), \mathrm{pH}_{0}=6.5-6.8$, and $\mathrm{pH}_{\mathrm{f}}=7.5-7.8$. Data plotted as mean of duplicates, and errors refer to standard deviation.

palladium (0.5 mM) as catalysts (Hurley and Shapley, 2007). However, in our study, when $\mathrm{MeReO}_{3}(0.5 \mathrm{mM})$ and $\mathrm{Pd}(0.5 \mathrm{mM})$ were also added to the CMC-stabilized ZVI nanoparticles, no improvement in perchlorate degradation was observed.

\subsection{Effect of background chloride or salinity}

As discussed earlier, chloride is one of the key products in perchlorate degradation, and will accumulate as the reaction proceeds. Moore et al. (2003) reported that the presence of $28.2 \mathrm{mM}$ (or $1.0 \mathrm{gL}^{-1}$ ) of chloride nearly ceased perchlorate degradation by commercial iron filings (size $=20-100$ mesh). On the other hand, it is practically very desirable to destroy perchlorate in saline water or spent IX brine, where high concentrations of perchlorate are co-present with high concentrations of chloride and/or other salts (Gingras and Batista, 2002; Xiong et al., 2006).

Fig. 7 shows the degradation kinetics of perchlorate in the presence of chloride (added as $\mathrm{NaCl}$ ) from 0.1 to $36.4 \mathrm{gL}^{-1}$ $(0.02-6 \% \mathrm{w} / \mathrm{w}$ as $\mathrm{NaCl})$. The degradation profile with $0.1 \mathrm{gL}^{-1}$ of $\mathrm{Cl}^{-}$nearly coincided with that when no chloride was added (with the same $k_{\text {obs }}$ of $0.0018 \mathrm{~min}^{-1}$ ). When chloride concentration was increased to higher levels $\left(1.0\right.$ and $\left.10 \mathrm{gL}^{-1}\right)$, perchlorate reduction was actually enhanced. For example, the $k_{\text {obs }}$ value was 0.022 and $0.0027 \mathrm{~min}^{-1}$ at $\mathrm{Cl}^{-}=1.0$ and $10 \mathrm{gL}^{-1}$, respectively, a $22 \%$ and $50 \%$ increase compared with that when $\mathrm{Cl}^{-}$was absent. On the other hand, Gotpagar et al. (1999) reported that pretreatment of the iron surface by chloride ions was able to enhance the initial degradation rate of trichloroethylene with ZVI. Johnson et al. (1998) observed that addition of chloride ions increased the rate of $\mathrm{CCl}_{4}$ dechlorination with ZVI by as much as four times.

The reaction enhancement by chloride can be attributed to two factors. First, the addition of chloride ions can enforce the breakdown of the thin film of iron (hydr)oxides on ZVI surface. Hard Lewis base ions (such as $\mathrm{Cl}^{-}, \mathrm{Br}^{-}$, and $\mathrm{I}^{-}$) were reported to be especially aggressive toward the passivating oxide layers to form strong complexes with iron centers (Gotpagar et al., 1999; Johnson et al., 1998). As the oxide layers are broken down by these diffusing anions, more ZVI surface becomes available for perchlorate reduction, resulting in improved perchlorate degradation. Second, chloride can promote localized corrosion on iron with irregular pit shapes, and pitting on the iron surface provides added reactive sites for perchlorate reduction (Gotpagar et al., 1999; Prinz and Strehblow, 1998).

However, when the chloride concentration was increased from 10 to $36.4 \mathrm{gL}^{-1}, k_{\text {obs }}$ was decreased only by $23 \%$ (to $0.0023 \mathrm{~min}^{-1}$ ), although this value is still $27 \%$ greater than that when no $\mathrm{NaCl}$ was added. This observation indicates that at the extremely high concentration of chloride, the competition of chloride ions with perchlorate for the sorption sites becomes prohibitively fierce as the beneficial effects of salinity are overweighed. Nonetheless, Fig. 7 shows that in the presence of $6 \% \mathrm{NaCl} 87.4 \%$ of $100 \mathrm{mgL}^{-1} \mathrm{ClO}_{4}^{-}$was destroyed by $1.8 \mathrm{gL}^{-1}$ of CMC-stabilized ZVI nanoparticles at $95^{\circ} \mathrm{C}$ in $450 \mathrm{~min}$, indicating that the stabilized ZVI nanoparticles can effectively destroy perchlorate in typical IX brine.

As indicated by Eq. (2), as perchlorate is converted to chloride, $\mathrm{Fe}$ is oxidized to $\mathrm{Fe}^{2+}$. The resultant ferrous ions are non-toxic and can be either reused or removed. For example, in case of IX brine treatment, the added chloride from perchlorate reduction actually enhances the regenerating power of the brine, and thus it is desirable to reuse the brine for regeneration. As perchlorate is re-concentrated in the reused brine, new ZVI nanoparticles can be produced in situ by reducing the existing $\mathrm{Fe}^{2+}$ ions in the brine with borohydride. Given the fairly low solubility of $\mathrm{Fe}^{2+}$ (e.g. $44 \mathrm{mgL}^{-1}$ at $\mathrm{pH} 8.0$ ), it can be removed, if desired, either by slightly raising the $\mathrm{pH}$ or by converting it to even less insoluble $\mathrm{Fe}^{3+}$ under ambient conditions. 


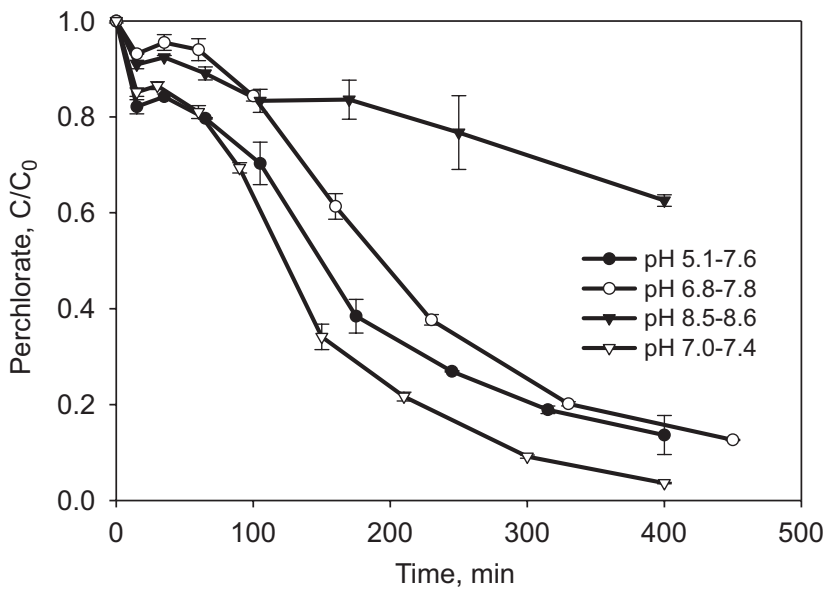

Fig. 8 - Effect of $\mathrm{pH}$ on perchlorate reduction by CMCstabilized ZVI nanoparticles in the presence of $6 \% \mathrm{NaCl}(\mathrm{w} / \mathrm{w})$ at $95^{\circ} \mathrm{C}$. Initial $\left[\mathrm{ClO}_{4}^{-}\right]=100 \mathrm{mg} \mathrm{L}^{-1}, \mathrm{ZVI}$ dose $=1.8 \mathrm{~g} \mathrm{~L}^{-1}$, $\mathrm{CMC}=0.9 \%(\mathrm{w} / \mathrm{w})$. The $\mathrm{pH}$ given refers to initial and final $\mathrm{pH}$. Data plotted as mean of duplicates, and errors refer to standard deviation.

\subsection{Effect of $\mathrm{pH}$ on perchlorate reduction.}

As revealed by Eqs. (1) and (2), hydrogen activity (pH) can affect corrosion of iron as well as degradation of perchlorate. Fig. 8 shows perchlorate reduction using $1.8 \mathrm{gL}^{-1} \mathrm{CMC}$ stabilized ZVI nanoparticles in the presence of $6 \%(\mathrm{w} / \mathrm{w}) \mathrm{NaCl}$ at $95^{\circ} \mathrm{C}$ and at various solution $\mathrm{pH}$ values. When the initial $\mathrm{pH}$ was 8.5 , only $27.4 \%$ perchlorate was removed after $400 \mathrm{~min}$ with a $k_{\text {obs }}$ of $0.0010 \mathrm{~min}^{-1}$, which is $56.5 \%$ lower than at an initial pH of $6.8\left(k_{\mathrm{obs}}=0.0023 \mathrm{~min}^{-1}\right)$. The observed decrease in perchlorate degradation rate can be attributed to the formation of ferrous hydroxide and/or ferric hydroxide precipitates on the ZVI nanoparticle surface at elevated $\mathrm{pH}$. The precipitates hinder the contact between ZVI nanoparticles surface and perchlorate, resulting in slower perchlorate reduction. Indeed, red precipitates were observed when the reacted ZVI solution at $\mathrm{pH} 8.5$ was filtered through a $0.22 \mu \mathrm{m}$ membrane filter. In contrast, faster perchlorate reduction kinetics $\left(k_{o b s}=0.0054 \mathrm{~min}^{-1}\right)$ was observed when the initial $\mathrm{pH}$ was lowered to 5.1. Because lower $\mathrm{pH}$ promotes both iron corrosion (Eq. (1)) and perchlorate degradation (Eq. (2)), this observation suggests that overall perchlorate reduction by ZVI nanoparticles is favored at lower $\mathrm{pH}$. When a buffer $(5 \mathrm{mM}$ HEPES) was applied to hold solution $\mathrm{pH}$ in a range of 7.0-7.4, the degradation rate was greatly improved $\left(k_{\mathrm{obs}}=0.0092 \mathrm{~min}^{-1}\right)$.

\section{Conclusions}

Major findings and conclusions from this study are summarized as follows:

(1) Perchlorate in both fresh water and brine can be rapidly and completely destroyed by low concentrations of stabilized ZVI nanoparticles at moderately elevated tem- peratures. Based on the surface-area-normalized rate constant $k_{\mathrm{SA}}$, starch- and CMC-stabilized ZVI nanoparticles degraded perchlorate 1.8 and 3.3 times, respectively, faster than non-stabilized ZVI particles. The activation energy $\left(E_{a}\right)$ for the reaction was determined to be $52.59 \pm 8.41 \mathrm{~kJ} \mathrm{~mol}^{-1}$. The nanoparticles were able to completely reduce perchlorate to chloride without accumulation of any intermediate products.

(2) Temperature was found to be a critical factor for perchlorate reduction. The observed pseudo-first-order rate constant $\left(k_{\text {obs }}\right)$ increased by 82 times (from 0.0002 to $0.0164 \mathrm{~min}^{-1}$ ) when the temperature was increased from 25 to $110^{\circ} \mathrm{C}$.

(3) Unlike degrading chlorinated organics, the presence of trace amounts $(0.3 \%$ of $\mathrm{Fe})$ of a metal catalyst $(\mathrm{Al}, \mathrm{Cu}, \mathrm{Co}$, $\mathrm{Ni}, \mathrm{Pd}$, or Re) did not show any reaction improvement. On the contrary, the presence of Pd reduced the reaction rate by $44.5 \%$. The inhibitive effect is attributed to accelerated corrosion reaction of the ZVI nanoparticles, which diminished the reducing power of the nanoparticles for perchlorate.

(4) The stabilized ZVI nanoparticles can highly effectively destroy perchlorate in saline water or IX brine. The presence of high concentrations of $\mathrm{NaCl}$ (up to $6 \% \mathrm{w} / \mathrm{w}$ ) increased perchlorate reduction rates by as high as $53 \%$.

(5) Solution $\mathrm{pH}$ can also affect the perchlorate reduction by ZVI nanoparticles. When the initial solution $\mathrm{pH}$ was lowered from 6.8 to 5.1, the perchlorate reduction rate was increased by 2.3 times. When a buffer solution $(5 \mathrm{mM}$ HEPES) was applied and $\mathrm{pH}$ was kept in the range of 7.0-7.4, the reaction rate was increased by $\sim 4$ times than without $\mathrm{pH}$ control.

The stabilized ZVI nanoparticles may offer an alternative means for completely destroying perchlorate in water that is small in volume and high in concentration such as perchlorate in source zones or IX brine.

\section{Acknowledgments}

The authors are grateful to Mr. Feng He for his assistance with preparation and characterization of the ZVI nanoparticles, and to Drs. Juncheng Liu and Ram B. Gupta for their assistance with TEM and DLS analyses. Partial financial supports from the USEPA STAR program (GR832373) and the USGS-Alabama Water Resources Research Institute are gratefully acknowledged.

R E F E R E N C E S

Abu-Omar, M.M., 2006. Metal mediated perchlorate reduction. Preprints of extended abstracts presented at the ACS National Meeting, vol. 46 (2), Division of Environmental Chemistry, American Chemical Society, pp. 413-415.

Abu-Omar, M.M., McPherson, L.D., Arias, J., Bereau, V.M., 2000. Clean and efficient catalytic reduction of perchlorate. Angew. Chem. Int. Ed. 39 (23), 4310-4313.

Blount, B.C., Pirkle, J.L., Osterloh, J.D., Valentin-Blasini, L., Caldwell, K.L., 2006. Urinary perchlorate and thyroid hor- 
mone levels in adolescent and adult men and women living in the United States. Environ. Health Perspect. 114 (12), 1865-1871.

Cai, Y., Espenson, J.H., 2005. Catalysis by methyltrioxorhenium(VII): reduction of hydronium ions by europium(II) and reduction of perchlorate ions by europium(II) and chromium(II). Inorg. Chem. 44 (3), 489-495.

Cao, J., Elliott, D., Zhang, W.X., 2005. Perchlorate reduction by nanoscale iron particles. J. Nanopart. Res. 7, 499-506.

Chen, W., Cannon, F.S., Rangel-Mendez, J.R., 2005. Ammoniatailoring of GAC to enhance perchlorate removal. II: Perchlorate adsorption. Carbon 43 (3), 581-590.

Gingras, T.M., Batista, J.R., 2002. Biological reduction of perchlorate in ion exchange regenerant solutions containing high salinity and ammonium levels. J. Environ. Monit. 4 (1), 96-102.

Gotpagar, J., Lyuksyutov, S., Cohn, R., Grulke, E., Bhattacharyya, D., 1999. Reductive dehalogenation of trichlorethylene with zerovalent iron: surface profiling microscopy and rage enhancement studies. Langmuir 15, 8412-8420.

Gu, B., Brown, G.M., Maya, L., Lance, M.J., Moyer, B.A., 2001. Regeneration of perchlorate $\left(\mathrm{ClO}_{4}^{-}\right)$-loaded anion exchange resins by a novel tetrachloroferrate $\left(\mathrm{FeCl}_{4}^{-}\right)$displacement technique. Environ. Sci. Technol. 35 (16), 3363-3368.

Gu, B., Dong, W., Brown, G.M., Cole, D.R., 2003. Complete degradation of perchlorate in ferric chloride and hydrochloric acid under controlled temperature and pressure. Environ. Sci. Technol. 37 (10), 2291-2295.

Gu, B., Bonnesen, G.P., Sloop, F.V., Brown, G.M., 2006. Titanium catalyzed perchlorate reduction and applications. In: $\mathrm{Gu}, \mathrm{B}$., Coats, J.D. (Eds.), Perchlorate, Environmental Occurrence, Interactions and Treatment. Springer Science+Business Media, Inc., New York, NY, pp. 373-386.

Gurol, M.D., Kim, K., 2000. Investigation of perchlorate removal in drinking water sources by chemical methods. In: Urbansky, E.T. (Ed.), Perchlorate in the Environment. Kluwer Academic/Plenum Publishers, New York, NY, pp. 99-108.

Hatzinger, P.E., 2005. Perchlorate biodegradation for water. Environ. Sci. Technol. 39 (11), 239A-247A.

He, F., Zhao, D., 2005. Preparation and characterization of a new class of starch-stabilized bimetallic nanoparticles for degradation of chlorinated hydrocarbons in water. Environ. Sci. Technol. 39 (9), 3314-3320.

He, F., Zhao, D., Liu, J., Roberts, C.B., 2007. Stabilization of Fe-Pd nanoparticles with sodium carboxymethyl cellulose for enhanced transport and dechlorination of trichloroethylene in soil and groundwater. Ind. Eng. Chem. Res. 46 (1), 29-34.

Huang, Y.H., Zhang, T.C., 2004. Effects of low pH on nitrate reduction by iron powder. Water Res. 38, 2631-2642.

Hurley, K.D., Shapley, J.R., 2007. Efficient heterogeneous catalytic reduction of perchlorate in water. Environ. Sci. Technol. 41 (6), 2044-2049.

Johnson, T.L., Scherer, M.M., Tratnyek, P.G., 1996. Kinetics of halogenated organic compound degradation by iron metal. Environ. Sci. Technol. 30 (8), 2634-2640.

Johnson, T.L., Fish, W., Gorby, Y.A., Tratnyek, P.G., 1998. Degradation of carbon tetrachloride by iron metal: complexation effects on the oxide surface. J. Contam. Hydrol. 29, 379-398.

Kanel, S.R., Greneche, J.M., Choi, H., 2006. Arsenic(V) removal from groundwater using nano scale zero-valent iron as a colloidal reactive barrier material. Environ. Sci. Technol. 40 (6), 2045-2050.

Kirk, A.B., Martinelango, P.K., Tian, K., Dutta, A., Smith, E.E., Dasgupta, P.K., 2005. Perchlorate and iodide in dairy and breast milk. Environ. Sci. Technol. 39 (7), 2011-2017.

Logan, B.E., LaPoint, D., 2002. Treatment of perchlorate- and nitrate-contaminated groundwater in an autotrophic, gas phase, packed-bed bioreactor. Water Res. 36, 3647-3653.
Lowry, G.V., Liu, Y., 2006. Nanoiron: reactant or catalyst? In: Proceedings of the Division of Environmental Chemistry for the 232nd ACS National Meeting, San Francisco, CA, September 10-14, 2006.

Min, B., Evans, P.J., Chu, A.K., Logan, B.E., 2004. Perchlorate removal in sand and plastic media bioreactors. Water Res. $38,47-60$.

Moore, A.M., Young, T.M., 2005. Chloride interactions with iron surfaces: implications for perchlorate and nitrate remediation using permeable reactive barriers. J. Environ. Eng. 131 (6), 924-933.

Moore, A.M., De Leon, C.H., Young, T.M., 2003. Rate and extent of aqueous perchlorate removal by iron surfaces. Environ. Sci. Technol. 37 (14), 3189-3198.

Oh, S.Y., Chiu, P.C., Kim, B.J., Cha, D.K., 2006a. Enhanced reduction of perchlorate by elemental iron at elevated temperatures. J. Hazard. Mater. 129 (1-3), 304-307.

Oh, S.Y., Cha, D.K., Chiu, P.C., Kim, B.J., 2006b. Zero-valent iron treatment of RDX-containing and perchlorate-containing wastewaters from an ammunition-manufacturing plant at elevated temperatures. Water Sci. Technol. 54 (10), 47-53.

Parette, R., Cannon, F.S., Weeks, K., 2005. Removing low ppb level perchlorate, RDX, and HMX from groundwater with cetyltrimethylammonium chloride (CTAC) pre-loaded activated carbon. Water Res. 39 (19), 4683-4692.

Prinz, H., Strehblow, H.H., 1998. Investigations on pitting corrosion of iron in perchlorate electrolytes. Corros. Sci. 40 (10), 1671-1683.

Rikken, G.B., Kroon, A.G.M., vanGinkel, C.G., 1996. Transformation of (per)chlorate into chloride by a newly isolated bacterium: reduction and dismutation. Appl. Microbiol. Biotechnol. 45 (3), 420-426.

Snyder, S.A., Vanderford, B.J., Rexing, D.J., 2005. Trace analysis of bromate, chlorate, iodate, and perchlorate in natural and bottled waters. Environ. Sci. Technol. 39 (12), 4586-4593.

Tripp, A.R., Clifford, D.A., 2004. Selectivity considerations in modeling the treatment of perchlorate using ion-exchange processes. Ion Exchange Solvent Extract. 16, 267-338.

Tripp, A.R., Clifford, D.A., 2006. Ion exchange for the remediation of perchlorate-contaminated drinking water. J. AWWA 98, 105-114.

Urbansky, E.T., 1998. Perchlorate chemistry: implications for analysis and remediation. Biorem. J. 2 (2), 81-95.

US Government Accountability Office (USGAO), 2005. Perchlorate: a system to track sampling and cleanup results is needed. GAO-05-462. 〈http://www.gao.gov/cgi-bin/getrpt?GAO-05-462〉 (accessed on August 30, 2006).

Wang, C.B., Zhang, W.X., 1997. Synthesizing nanoscale iron particles for rapid and complete dechlorination of TCE and PCBs. Environ. Sci. Technol. 31 (7), 2154-2156.

Wilkin, R.T., Su, C., Ford, R.G., Paul, C.J., 2005. Chromium-removal processes during groundwater remediation by a zero-valent iron permeable reactive barrier. Environ. Sci. Technol. 39 (12), 4599-4605.

Wolff, J., 1998. Perchlorate and the thyroid gland. Pharmacol. Rev. 50 (1), 89-105.

Xiong, Z., Dimick, P., Zhao, D., Kney, A., Tavakoli, J., 2006. Removal of perchlorate from contaminated water using a regenerable polymeric ligand exchanger. Sep. Sci. Technol. 41, 2555-2574.

Xu, J., Song, Y., Min, B., Steinberg, L., Logan, B.E., 2003. Microbial degradation of perchlorate: principles and applications. Environ. Eng. Sci. 20, 405-422.

Yang, G.C.C., Lee, H.L., 2005. Chemical reduction of nitrate by nanosized iron: kinetics and pathways. Water Res. 39, 884-894.

Yoon, J., Yoon, Y., Amy, G., Cho, J., Foss, D., Kim, T.H., 2003. Use of surfactant modified ultrafiltration for perchlorate $\left(\mathrm{ClO}_{4}^{-}\right)$removal. Water Res. 37 (9), 2001-2012. 